\title{
Patriotic education as part of history classes for students of engineering universities
}

\author{
Svetlana Nikonova ${ }^{10000-0003-0196-914 X]}$, and Elena Bureyeva ${ }^{1 *[0000-0002-2274-9931]}$ \\ ${ }^{1}$ Kazan State University of Architecture and Engineering, 420043, Zelenaya st., Kazan, Russia
}

\begin{abstract}
Patriotic education is an important and integral part of the learning process for students. This paper proposes patriotic education technologies tested at the Kazan State University of Architecture and Engineering when teaching history as part of the Fakel project (Torchlight). In this project, students record the accounts of the Great Patriotic War veterans, study family archives and Internet-based databases to collect and summarize the details of the war events. This technology helps better engage students in studying and writing historical reports to cover the events of personal importance from their family history. This improves understanding of history and historical research skills; it instills love and respect for the country and for the people, while the participants also become civic-minded as a result. The Project has involved more than a thousand students over ten years, which is a sign of success and students' great interest in it.
\end{abstract}

Keywords: building universities, patriotic education, learning technology, teaching history, young students, memory collection.

\section{Introduction}

Patriotic education of young people has traditionally been on the core ideological agenda of the state; it is a problem addressed through public and governmental organizations, educational and spiritual institutions. Sociological studies of the last five years show that patriotic education remains an important and socially significant problem [1-4]. Today, patriotic education needs to employ both the conventional methods and the breakthrough technologies that can help to instill appropriate values, principles and worldview, help to shape in a young person such traits as civic-mindedness, responsibility, respect for the country and its history, honesty, and decency. The problem of patriotic education in the process of students' socialization is considered in the works [5-7]. One of the important resources that patriotic education can use is historical memory linking generations. The problem of preserving historical memory in patriotic education is presented in the works [812]. The definition of the concept of patriotism and specific methods of its formation based on a synthesis of modern technologies have been widely investigated [13-16]. Dickvan Straaten pointed out that teachers must engage students in building «images of time» [17, 18]. This is what the Fakel project of the Kazan State University of Architecture and

*Corresponding author: bureeva27@yandex.ru 
Engineering focuses on. Students involved in this Project are tasked, among other things, to recreate the history of their families by studying family and state archives, historical photographs and footage, electronic databases and other sources. The Great Patriotic War (translator's note: term used in Russia to describe the events of the Eastern Front in World War II) and its history have always been in the spotlight of research in Russia, mainly as a source of patriotism and pride for the Fatherland. Historical memory of the war is an element of the society's self-identification and consolidation. Today's historical research uses innovative methods and technologies as well as electronic resources. According to Lévesque patriotic education and good understanding of history are closely bound [19, 20]. The proposed patriotic education technology has a great teaching and learning potential. Young students are active in all stages of this Project. It brings together research and education (in the sense of instilling specific moral traits), as the Project output helps students remember history, be more patriotic, and create a base of information sources on the war history.

\section{Materials and methods}

This paper analyzes teachers' work as part of the Fakel project of the Kazan State University of Architecture and Engineering. The project aims to motivate students to study history, be patriotic and civic-minded by the virtue of collecting memories of the Great Patriotic War. The University started the project in 2009. It was based on a set of materials that comprised: questionnaires for different categories of war veterans (combatants, home front workers, children and adolescents); interview guidelines; research guidelines; Internet search guidelines. Over ten years, the Project has involved more than a thousand students who collected and recorded the accounts of war veterans from the Republic of Tatarstan, Bashkiria, Mari El, Kirov region. This joint teacher-student effort has produced a large base of documents from family archives: letters from the front, photographs, medals, newspaper cutouts, etc. This patriotic education technology has performed well, as it tackles multiple aspects of education: it improves understanding of history and research skills, instills patriotism, and shapes the worldview behind the student's future professional work.

\section{Results}

The Kazan State University of Architecture and Engineering's Student Council initiated the collection of data on the Great Patriotic War (GPW) veterans and other witnesses of the war events. Students involved in the project show their great interest in the war history and then in the general history of the country as it embraced the history of their families. It is the family history that the students are most interested in and have the greatest trust in as a source of information [11]. The project is staged as follows:

Stage 1. Teachers discuss the Fakel Project during the introductory session of the history class and invited students to take part in it.

Stage 2. Interested students create an initiative group and elect its coordinator.

Stage 3. Students have to talk to their families to decide who to interview; alternatively, they can find a GPW veteran in their city or town. To that end, they can use the Public Associations of Veterans, their home schools, or the Internet.

Stage 4. Students use the guidelines and the Questionnaire printout (Appendix 1) to interview veterans and their families.

Appendix 1.

Questionnaire for interviewing a veteran of the Great Patriotic War

Questions: 
1) When and how did you learn that the war had begun? What was your, your friends' and family's reaction?

2) How did your life change when the war began?

3) Whom and how did you see going to war?

4) How did you help adults?

5) What did you do and how did your parents handle the food-related challenges? Which food was a kind of delicacy or a treat for you?

6) Did you play games? Did the war change your games?

7) What did you do in your free time? Did you have an opportunity to read books or to study?

8) Now, please remember cases of mutual help. How did you help others and how did others help you?

9) Which year and day of war was the most difficult for you? What events were of the greatest grief for you?

10)What do you remember the most about different years of war from 1941 to 1945 ?

11)Did you have moments of despair? What gave you the strength to endure the hardships of war?

12) What is your most joyful memory of wartime?

13) What interesting or funny occasions of the war do you remember the most?

14)Did you celebrate anything? If you did, which were the most memorable?

15)Did you face the enemy during the war? If you did, under what circumstances?

16)Did any evacuees live next to you? What can you tell us about them?

17) When and under what circumstances did you learn about the Victory? What did you remember about Victory Day? What was your, your friends' and family's reaction? How did you meet the soldiers coming home triumphant?

18) How was your postwar life?

Stage 5. Validate and complete the collected data. For this stage, students have history teachers' assistance. Validation is a multiple-step effort. Almost any reported detail can be verified online on the following websites: http://podvignaroda.ru/?\#tab=navHome, https://pamyat-naroda.ru/, https://www.memo.ru/ru-ru/Projects/, or http://www.soldat.ru/. In some cases, search on these sites returns documentary evidence of a military unit's routes, a person's awards of honor, burial sites, or sundry military details.

Stage 6. Data collected by interviewing form a database of Great Patriotic War veterans, workers of the rear, and people evacuated to Kazan.

Stage 7. All collected accounts are summed up and published as student-authored monographs. These monographs can now be used for citation in war research or as textbooks in history classes.

The Project has produced four monographs: We Did Our Best to Bring This Day Closer (Rus: Этот день мы приближали, как могли), 2010; When We Were at War (Rus: Когда мы были на войне), 2013; We are Children of Hard Times (Rus: Мы сурового времени дети), 2015; We've Settled Old Scores With the War (Rus: С войной покончили мы счеты), 2020. These books contain more than 300 student-written essays. They dwell upon the Soviet citizens that now live in Russia or abroad. A remarkable characteristic of those essays is them being published in minority languages.

To create an all-embracing collective portrait of a Great Patriotic War veteran, students need to search for data (identify the personalities, collect memories, and clarify the biographies) and to write an emotion-driven yet accurate story of a specific event, person(s), or family. This story will reflect the mundane aspect of the history and each person will understand. The Fakel Project seeks to boost advanced research skills and understanding of history; at the same time, it is an educational project that instills in modern students the desire to learn the truth about their country's and people's history. 
Patriotic education is a complex process that involves many methods and aspects. It is a task of critical importance that seeks to shape the worldview and to preserve the generation links. Thus, the patriotic awareness and consciousness of Russian citizens remains a core value, a fundamental component of the spiritual and moral unity of the Russian society.

It is important to instill unconditional patriotism, which is possible in regions that have rich history and tradition, where the historical memory is preserved [13]. Tatarstan is one such region, which facilitates efforts. The project continues, and it is safe to say the studentcollected material is significant, unique, and original.

It has expanded the database, and the Project participants now go on to interview children of wartime. They use the collected materials (evidence of industrial and agricultural work, details of survival in occupied areas and concentration camps) to recreate the world of war as seen through children's eyes.

\section{Conclusions}

Patriotic education of university students is a complex, multifaceted process that must make use of novel technologies. Engagement through personal interest has a great role to play in the process. It is only linking the student's experience to specific historical events that makes the understanding of such events truly emotion-driven. The Project has done a lot over the decade: it produced an electronic database of the Great Patriotic War veterans, workers of the rear, and children of wartime; students have published collections of GPW memories. The historical memory of the Great Patriotic War is an integral part of the Russian national consciousness; in recent decades, it has evolved into one of those few elements that unite the nation. What makes student patriotic projects stand out is their pronounced focus on education. Visits to veterans, interviewing, and processing of the results to expand the database is all done by the students involved in the Fakel Project. Thus, research and education go hand in hand in this Project; its output creates historical and collective memory while also producing the theory behind a model of patriotic education of students [8]. Researching the GPW materials motivates students to study history in an informal fashion. The project involves students who interpret patriotism as a real effort to preserve historical memory and to create a whole new attitude towards the historical and cultural heritage of different peoples [21].

Among other things, the project sought to restore the combat history of militants from documents including state and family archives as well as electronic databases. Global experience shows that patriotic education is based on learning military and historical traditions. Student involvement in such projects is a socially beneficial work that young people find interesting and that helps instill civic-mindedness, shapes the worldview to support future professional work, focuses on socially significant goals, and contributes to the social and historical consciousness of a person. This work brings together people of different ethnicities and shows young people how important it is to respect their history while also strengthening the generation links. The ongoing and rapidly expanding memory research of the recent decades shows that interpreting the past is crucial for different aspects of social and political life, which means such interpretations must be made carefully [4]. The project has proven to address not only teaching challenges, but also historical research as it has opened new pages in the country's history. Thus, it would be wrong to consider the project merely an educational tool. This is a patriotic education technology that can be interpreted as a research-based activity. Research ethics is key. Today, instilling patriotism in students is imperative. A number of legal acts, events, programs and aids that tackle the issues of instilling patriotism, morality, and civic-mindedness confirm the importance of patriotic education. The society needs well-educated people of great professional culture, mobility, constructiveness, and acute sense of responsibility for their 
country. Present day's strategy of patriotic education should definitely use conventional methods and activities (searching, support for young people's patriotic initiatives, etc.). However, it must also include what novel technologies bring to the table to combine conventional and novel activities that students find entertaining and important. Patriotic student projects have traditionally been focused on retrieving information from the Great Patriotic War materials, which motivates young people to study different periods of Russia's history as well as its different aspects (wartime childhood, daily life, etc.); thus, this focus recreates a holistic picture of historical past while also curbing any attempt to falsify Russia's history.

\section{Discussions}

Patriotic education of students has been researched by specialists of different humanities. Some sociological studies undertaken by Russian universities prove patriotic education relevant and necessary, especially when it comes to the civic-mindedness of students and how it emerges [2]. S. Alieva believes that the main task of higher education institution teachers is to help the youth to make a stand for the moral, esthetic, social values and to promote establishment of the civic spirit and patriotism with all peoples of Russia [5].

Education is bound to learning history. In this regard, the trustworthiness of different sources becomes important. Researchers believe one cannot limit oneself to archives, documents, and sundry objective evidence today, as it is important to include one's own impressions and experiences in such studies [22]. This is because today's students are critical of academic literature and put more trust in their families' stories. An Arizona State University poll of 2016 showed that students trust personal sources of information (family stories) more [11].

History teachers usually focus on understanding the past as an end in itself. Studies have shown many students perceive that as pointless and dull. Yet history is of tantamount importance when focusing on the present and on the future. This is why teachers must well be capable of showing the students how closely the past and the future are linked. They must engage students in building «images of time» [17]. This idea sees light in many teaching technologies and is suitable for patriotic education.

Improving the understanding of history is an important component of teaching history at a university. Learning history contributes to patriotism. Thus, patriotic education and good understanding of history are closely intertwined. This is best attained when a student is personally interested in studies and feels involved in the events he or she's researching. Such approach manifests when studying the history of war by collecting the family accounts of it [20]. The presented project, in which the Engineering University students collect memories, only proves this statement. Students themselves understand the importance of traditional spiritual and moral values that regulate the social behaviors. They name love for the family, love for the Motherland, and preservation of collective memory as such values.

Collective memory is an interdisciplinary concept subject to wide discussion; it includes the attitude of interconnected social groups to their past and the present. Students born after the collapse of the USSR have only a vague idea of the realities of Soviet life; however, they show great interest in it when listening to their parents' stories [12]. The Project helps students get it in an interesting format.

Student-parent-teacher cooperation is integral to the project. Researchers note that the emotion-driven perception of information and personal interest are of great importance for learning and education [23].

In today's history, the Internet and other technologies have become important tools for researching and teaching the past. Use of web-based resources and various sources 
sometimes enables a novel interpretation of historical events [16]. Accordingly, the idea is not to discard the Internet as a source of information, but to teach students to use it appropriately.

The project has shown patriotic education of students to be an effective part of teaching history by using a variety of methods to boost cognition and learning, understanding of history, database skills, and personal interest.

\section{References}

1. S. A. Magaril, Meanings of Patriotism - Historical Transformation, Sotsiologicheskie issledovaniya [Sociological Studies], 1, 142-151, (2016)

2. A. S. Magranov, L. S. Detochenko, Civilidentity of modern students: featuresandfactorsoftransformation, Sotsiologicheskie issledovaniya [Sociological Studies], 8, 108-116, (2018) DOI: 10.31857/S013216250000766-5

3. E. I. Pronina, Civic and patriotic formation specifics among high school students. Sotsiologicheskie issledovaniya [Sociological Studies], 5, 97-103, (2011)

4. P. Wawrzynski, J. Marszalek-Kawa, Promotion of national heroes as civic role-models during democratization, New Educational Review, 52(2), 101-111, (2018) DOI: $10.15804 /$ tner.2018.52.2.08

5. S. A. Alieva, S. Z. Zakaryaeva, O. N. Omarov, R. V. Radjabova, E. A. Kimpaeva, P. D. Gadjieva, .Scientific and Pedagogical Bases of Civic and Patriotic Upbringing of Young Students, Journal of Educational and Social Research, 9(3), 160-169, (2019) DOI:10.2478/jesr-2019-0033

6. J. Kleinig, S. Keller and I. Primoratz, The ethics of patriotism: A debate. (Wiley Blackwell, Oxford, 2015)

7. S. Savchenko, V. Kurylo, Patriotic education in the process of youth socialization in conditions of hybrid warfare, The Journal of Social Sciences Research, 5, 1121-1125 (2018) DOI: 10.32861/jssr.spi5.1121.1125

8. T. B. Gongaware, Collective memory anchors: Collective identity and continuity in social move-ments, Sociological Focus, 43(3), 214-239, (2010) DOI:10.1080/00380237.2010.10571377

9. V. N. Gulyaikhin, O. E. Andryuschenko, P. P. Fantrov, Traditional moral values in the associations of students of the volgograd region, Sotsiologicheskie issledovaniya [Sociological Studies], 11, 146-151, (2018) DOI: 10.31857/S013216250002794-6

10. E. M. Dorozhkin, M. R. Moskalenko, M. B. Larionova, E. A. Kazantseva, N. E. Loginova, Peculiar features of teaching history to economist students in Russian universities, Humanities and Social Sciences Reviews 7(4), 1366-1371, (2019) DOI: 10.18510/hssr.2019.74190

11. Lauren McArthur Harris, Anne-Lise Halvorsen, Gerardo J. Aponte-Martínez, "[My] family has gone through that»: How high school students determine the trustworthiness of historical documents, The Journal of Social Studies Research, 40(2), 109-121, (2016) DOI: 10.1016 / j.jssr.2015.06.007

12. V. Kasamara, A. Sorokina, Post-Soviet collective memory: Russian youths about Soviet past, Communist and Post-Communist Studies, 48(2-3), 137-145, (2015)

13. I. A. Khaliy, Patriotism in the Russian: Typology, Sotsiologicheskie issledovaniya [Sociological Studies], 2, 67-74. (In Russ.) (2017)

14. R. C. Alves, Teaching history and public history: Historical knowledge and its social function, Dialogos, 22(3), 20-31, (2018) DOI: 10.4025/dialogos.v22i3.45775

15. I. Bekh, Patriotism as a value: essence and future prospects, Education: Modern Discourses, 1, 185-191 (2018) DOI: 10.32405/2617-3107-2018-1-18 
16. Kevin Kee, Kevin Bradley Kee, Pastplay: Teaching and learning history with technology, University of Michigan Press, (2014) DOI: http://dx.doi.org/10.3998/dh.12544152.0001.001

17. Dick Van Straaten, Arie Wilschut, Ron Oostdam, Making history relevant to students by connecting past, present and future: a framework for research, Journal of Curriculum Studies, 48 (4), 479-502 (2016)

18. Dick van Straaten, Arie Wilschut, Ron Oostdam, Connecting past and present through case-comparison learning in history: views of teachers and students, Journal of Curriculum Studies, 51(5), 643-663, (2019) DOI:10.1080/00220272.2018.1558457

19. S. Lévesque, History as $a^{\prime} G P S^{\prime}$ : On the uses of historical narrative for French Canadian students' life orientation and identity, London Review of Education, 15(2), 227-242 (2017) DOI: 10.21861/HGG.2010.72.02.06

20. S. Lévesque, P. Clark, Historical thinking: Definitions and educational, The Wiley International handbook of history teaching and learning, Wiley Blackwell, Hoboken, NJ 3(2), 119-148 (2018)

21. S. I. Nikonova, Education of patriotism of modern youth on the example of heroes of the Great Patriotic war (based on materials of «Torch» searching project), Gumanitarnyye nauki v 21 veke [Humanities in the $21^{\text {st }}$ century], 6, 70-77 (2016)

22. O. N. Cationov, A. O. Cationova, B. O. Mayer, Literary stories by military writers in the moral education of modern youth, Science for Education Today, 19(6), 107-120 (in Russian) (2019) DOI: 10.15293/2658-6762.1906.07

23. M. G. Nikitskaya, N. N. Tolstykh, Foreign studies of learning motivation: XXI century, Journal of Modern Foreign, 7(2), 100-113 (2018) DOI: $10.17759 /$ jmfp.2018070210 